\title{
Apresentação Políticas Públicas de Educação
}

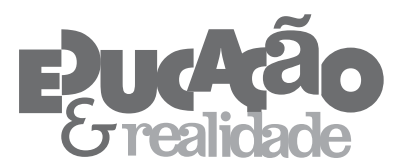

\author{
Nalú Farenzena' \\ 'Universidade Federal do Rio Grande do Sul (UFRGS), Porto Alegre/RS - Brasil
}

No segundo número de 2016, em tempos de comemoração dos 40 anos de Educação \& Realidade, a editoria apresenta a seção temática Políticas Públicas de Educação. Tal seção foi organizada através da reunião de textos de excelente qualidade acadêmica submetidos ao fluxo contínuo da Revista. Casualmente, o lançamento deste número se dá em um momento em que a agenda de políticas educacionais no Brasil adensa e se multiplica com ações e decisões públicas decorrentes da implementação do Plano Nacional de Educação (PNE) 2014-2024 e planos estaduais e municipais do mesmo setor, bem como pela implantação, ora plenamente vigente, da nova delimitação da obrigatoriedade escolar, para pessoas de 4 a 17 anos de idade na educação básica.

Neste último ano vivemos tempos conflituosos na política do País, com repercussões na política educacional, justo numa fase que demandaria maior estabilidade nas relações institucionais para a exposição e o aprofundamento dos debates em torno de decisões cruciais como o são aquelas relativas à constituição do Sistema Nacional de Educação. Esta, uma política constitutiva, à qual se interligam questões como a base nacional comum curricular, a cooperação federativa na educação, novos formatos no financiamento da educação, a gestão democrática da educação e das instituições de ensino, entre outros tantos temas pautados por atores governamentais e da sociedade civil em diferentes arenas de deliberação.

Educação \& Realidade, Porto Alegre, v. 41, n. 2, p. 309-311, abr./jun. 2016. 309 http://dx.doi.org/10.1590/2175-623663583 
Apresentação da Seção Temática - Políticas Públicas de Educação

A seção temática reúne nove artigos, de autores de diferentes instituições e latitudes, que exemplificam problemáticas referentes às políticas educacionais que têm sido objeto de atenção da academia, assim como abordagens e ferramentas de pesquisa e análise das quais se valem os pesquisadores no laborioso desafio de (re)construir analiticamente interesses, instituições, estratégias e/ou ideias envolvidas nos campos de possibilidade das policies. Sumarizo, na sequência, estes nove textos.

Possibilidades ligadas à efetivação dos planos estaduais de educação, elaboradas na vigência do Plano Nacional de Educação 2001-2010, é o tema do artigo de Donaldo Bello de Souza e Janaína Specht da Silva Menezes, intitulado Acompanhamento e Avaliação dos/nos Planos Estaduais de Educação 2001-2010. A análise de conteúdo de planos estaduais da década passada, no que concerne à previsão de meios institucionais de avaliação, pode oferecer, segundo os autores, elementos para a qualificação dos processos interligados de planejamento e avaliação da/na educação no decênio 2014-2024.

O planejamento da educação também é tema do artigo de Idevaldo da Silva Bodião, cujo título é Reflexões sobre as Ações da Sociedade Civil na Construção do PNE 2014/2014. O autor analisa a participação de um importante ator da sociedade civil na política educacional brasileira - a Campanha Nacional pelo Direito à Educação - na elaboração do PNE vigente, com o que são discutidos conceitos e práticas de democratização e participação social, no marco de contextos político e institucionais específicos.

Por meio de análise documental, entrevistas e observação, Ricardo Abdalla Barros e Maria Antonia Ramos de Azevedo discorrem sobre resultados de um programa governamental no trabalho de professores da rede estadual paulista. No artigo O Impacto do Programa São Paulo faz Escola em Professores Iniciantes, os autores mostram a redução na autonomia do trabalho docente em função do próprio desenho da política e outras medidas a ela associadas.

Assim como no texto anterior, Edileusa Esteves Lima e Lucília Regina de Souza Machado, no artigo Reuni e Expansão Universitária na UFMG de 2008 a 2012, exploram a implementação de uma política pública, neste caso o Programa de Apoio a Planos de Reestruturação e Expansão das Universidades Federais Brasileiras (Reuni). Esse Programa é caracterizado em termos gerais e sua execução, na UFMG, é analisada tendo em conta o cumprimento do plano de metas e vulnerabilidades que comprometem a eficácia.

Atuação em Rede e o Projeto Jovem de Futuro: a privatização do público, de autoria de Vera Maria Vidal Peroni e Maria Raquel Caetano, é um texto em que a temática das relações entre os setores público e privado na política educacional é examinada por meio de concepções e práticas de um projeto do Instituto Unibanco implementado em escolas

310 Educação \& Realidade, Porto Alegre, v. 41, n. 2, p. 309-311, abr./jun. 2016. 
públicas de ensino médio. As autoras adentram à rede de relações do Instituto Unibanco a fim de evidenciar modos e modelos de penetração de lógicas empresarias capitalistas nas políticas públicas.

Num momento em que a educação do campo busca constituir-se, na prática, como modalidade na estrutura da educação brasileira, Celi Nelza Zulke Taffarel e Cláudio de Lira Santos Júnior - no artigo intitulado Pedagogia Histórico-Crítica e Formação de Docentes para a Escola do Campo - fazem uma leitura crítica do programa governamental Escola Ativa, com ênfase para as ações da Universidade Federal da Bahia na sua implementação. Face a limites e contradições do Escola Ativa, os autores advogam propostas conceptuais para o programa substituto, voltado igualmente às escolas e classes multisseriadas do campo, o Escola da Terra.

Democracia, Micropolítica e os Dispositivos de Gestão Educacional Gerencial, de autoria de André Antunes Martins, problematiza a gestão gerencial e seus valores de mercado. Dispositivos de participação democrática da reforma do Estado da década de 1990 e a micropolítica deleuziana são objetos de dois momentos diferenciados do texto, confluindo para uma reflexão que articula participação democrática de corte gerencial com controle na/da sociedade.

O deslocamento de uma concepção de educação escolarizada pautada na unidade nacional para a concepção de diversidade cultural constitui a discussão de fundo do artigo Educação Patrimonial e Políticas de Escolarização no Brasil, de Rodrigo Manoel Dias da Silva. O autor reconstitui a trajetória de educação patrimonial com base em sentidos socialmente atribuídos à cultura e à educação em distintos momentos históricos.

O artigo intitulado Reflexões sobre Políticas de Educação Linguística em Contexto Plurilíngue alia a pesquisa histórica à análise de políticas. Nele, as autoras Maristela Pereira Fritzen e Luana Ewald discutem conflitos gerados por políticas de educação linguística propostas e implementadas durante a segunda campanha de nacionalização do ensino no Médio Vale do Itajaí, Santa Catarina, durante o Estado Novo. Movimentos de resistência a imposições culturais são destacados no texto.

Por fim, reitero, neste tempo de celebrar tanto tempo de publicação deste periódico, o empenho dos que trabalham e trabalharam na Educação \& Realidade no sentido de fazer chegar aos leitores produções acadêmicas designadas como qualificadas no curso de nosso processo editorial.

Uma proveitosa leitura!

Nalú Farenzena - Editora Associada 